\title{
Morphology of the lingual papillae in the sitatunga
}

\author{
By \\ Shoichi EMURA ${ }^{1}$, Toshihiko OKUMURA ${ }^{2}$ and Huayue CHEN ${ }^{3}$ \\ 1'Nursing Course, Gifu University School of Medicine, Gifu 501-1193, Japan
${ }^{2}$ Technical Section, Gifu University School of Medicine, Gifu 501-1194, Japan
${ }^{3}$ Department of Anatomy, Gifu University Graduate School of Medicine, Gifu 501-1194, Japan
}

- Received for Publication, February 7, 2011 -

\begin{abstract}
Key Words: $\quad$ sitatunga, lingual papillae, SEM
Summary: We examined the dorsal lingual surfaces of an adult sitatunga (Tragelaphus spekei) by scanning electron microscopy. Filiform, fungiform and vallate papillae were observed. The filiform papillae consisted of a larger main papilla and smaller secondary papillae. The filiform papilla contained connective tissue core consisting of several processes. The fungiform papillae were round in shape. The connective tissue core of the fungiform papilla was flower-bud shaped. Lenticular papillae were limited on the torus lingua. The connective tissue core of the lenticular papilla consisted of numerous small spines, or these spines and rod-shaped processes. The vallate papillae were flattened-oval shaped and the papillae were surrounded by a circular trench. The connective tissue core of the vallate papilla was covered with numerous small spines. These findings indicate that the tongue of the sitatunga is similar to that of the blackbuck and Barbary sheep.
\end{abstract}

\section{Introduction}

Many studies have been published on the structures of the lingual surfaces in various animals. In the order Artiodactyla, there have been many scanning electron microscopic (SEM) studies of the tongues of cows (Steflik et al., 1983; Camorro, 1986), serows (Funato et al., 1985; Atoji et al., 1998), one humped camels (Qayyum et al., 1988), buffalos (Scala et al., 1993), lesser mouse deer (Agungpriyono et al., 1995), blackbuck (Emura et al., 1999), Barbary sheep (Emura et al., 2000a), Bactrian camels (Eerdunchaolu et al., 2001) and hippopotamuses (Yoshimura et al., 2009). Such studies reveal variations in morphology and distribution of papillae on the dorsal lingual surface among animal species.

However, no SEM study on the tongues of the sitatunga has been carried out. This study three-dimensionally examined the dorsal lingual surface of the sitatunga, in order to compare results with those from previous reports on other mammals.

\section{Materials and Methods}

The tongue of an adult sitatunga (Tragelaphus spekei) of the family Bovidae was used in this study. The tongue was fixed in $10 \%$ formalin. Small blocks containing papil- lae were cut with a razor blade, post-fixed with $1 \%$ osmium tetroxide for $1 \mathrm{~h}$. Thereafter, the specimens were dehydrated through a graded series of acetone and criticalpoint-dried. To show the three-dimensional connective tissue structure of the lamina propria of the mucosa, some of the samples were washed in distilled water after fixation and macerated in $3.5 \mathrm{~N} \mathrm{HCl}$ at $35^{\circ} \mathrm{C}$ for 2 days. After maceration, tissues were washed in the distilled water and post-fixed in $1 \%$ osmium tetroxide for $1 \mathrm{~h}$, and dehydrated in a series of acetone and critical-point-dried. All specimens were sputtered with Pt-Pd before being examined under SEM (Hitachi S-3000N, Tokyo, Japan) at an accelerating voltage of $10 \mathrm{kV}$.

\section{Results}

\section{General observations}

Macroscopically, the tongue of the sitatunga is about $20 \mathrm{~cm}$ long and the lingual body has lingual prominence on the posterior third (Fig. 1). Fungiform papillae are round in shape and more densely distributed as compared to those of the lingual body on the tip and ventral surface of the lingual apex. There is no foliate papilla. Vallate papillae are located on both sides of the posterolateral aspect, and each papilla is surrounded by a groove (Fig. 1). 


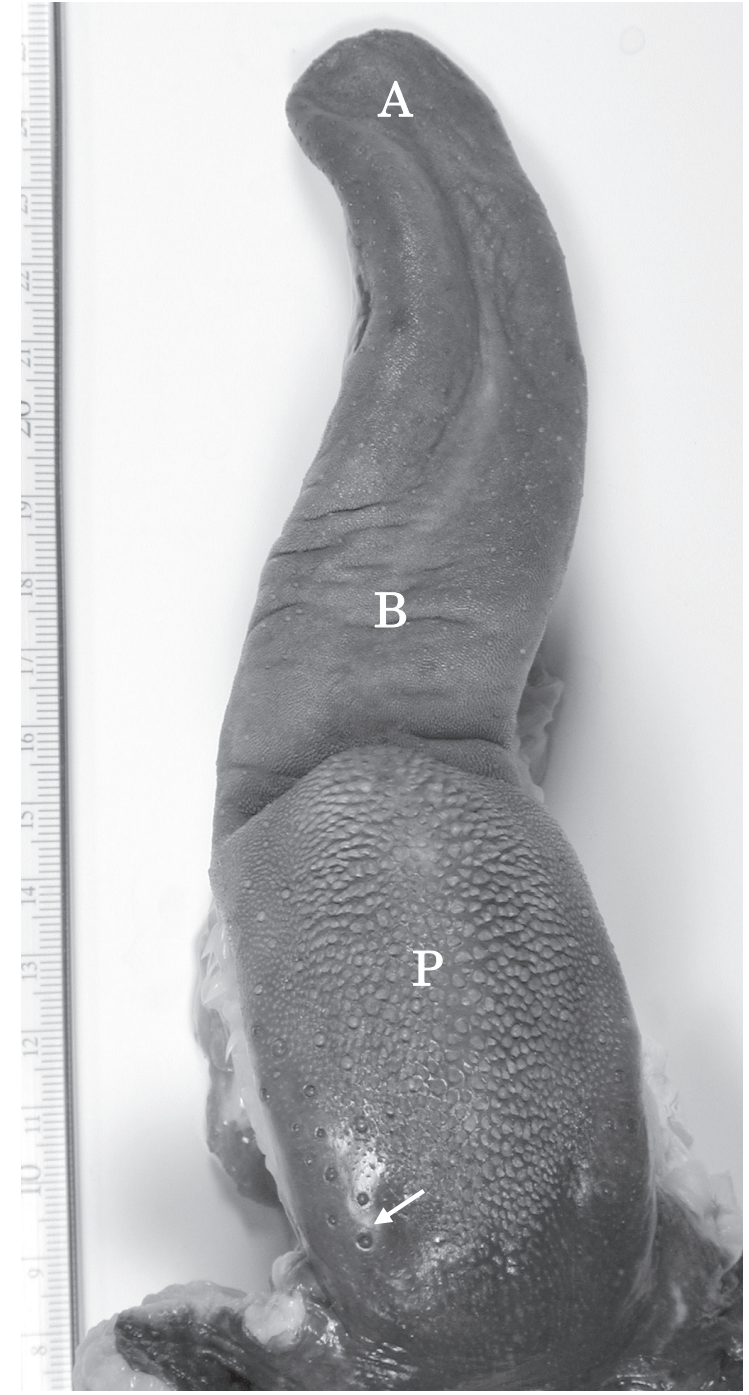

Fig. 1. Macrograph of a sitatunga tongue. $\mathrm{A}=$ lingual apex. $\mathrm{B}=$ lingual body. $\mathrm{P}=$ lingual prominence. Arrow $=$ vallate papilla.

\section{Scanning electron microscopy}

The filiform papillae consist of a larger main papilla and smaller secondary papillae (Fig. 2a). The filiform papilla contains the connective tissue core consisting of several processes (Fig. 2b). The fungiform papillae are round in shape (Fig. 2a). The connective tissue core of the fungiform papilla is flower-bud shaped (Fig. 2b). Lenticular papillae of various sizes are limited on the lingual prominence (Fig. 3a). The connective tissue core of the lenticular papilla consists of numerous small spines, or these spines and rod-shaped processes (Fig. 3b). The vallate papillae are flattened-oval shaped and the papillae are surrounded by a semicircular trench (Fig. 4a). The connective tissue core of the vallate papilla is covered with numerous small spines (Fig. 4b).

\section{Discussion}

Agungpriyono et al. (1995) reported that filiform papillae consist of a larger main papilla and smaller secondary papillae, and in the filiform papillae that the distribution of the secondary papillae in the lesser mouse deer, being present from the anterior part of the tongue to the end of the middle third and rare or absent in the posterior part, is relatively restricted. Atoji et al. (1998) observed filiform papillae and conical papillae, and reported that the filiform papillae have secondary papillae in the Formosan serow. Emura et al. (1999, 2000a) also observed similar filiform papillae in the blackbuck and Barbary sheep. The filiform papillae of the sitatunga in this study were morphologically similar to those of the blackbuck and Barbary sheep (Emura et al., 1999, 2000a). The appearance of the connective tissue cores of the filiform papillae distributed in sitatunga's tongue showed a slender flower bud-like core. The structure of the connective tissue core was similar to that of the lesser mouse deer (Emura et al., 2008).

The fungiform papillae were more densely distributed on the tip and ventral surface of the lingual apex in Japanese serow, Formosan serow, blackbuck and Barbary sheep, and the papillae were smaller than that of the body (Funato et al., 1985; Atoji et al., 1998; Emura et al., 1999, 2000a). These reports coincide with the findings on the sitatunga. The connective tissue core of the fungiform papilla on the sitatunga's tongue was flower-bud shaped. This finding was similar to that of the pronghorn (Yoshimura et al., 2000).

The vallate papillae surrounded by a groove was round or oval in shape (Funato et al., 1985; Atoji et al., 1998). It was reported that a pair of long-flat vallate papillae were observed in the lesser mouse deer tongue (Agungpriyono et al., 1995). Equine vallate papillae were composed of a primary papilla divided into several secondary papillae by intermediate grooves (Chamorro et al., 1986). In this study, the vallate papillae were flattened-oval shaped and the papillae were surrounded by a semicircular trench. The connective tissue of the round central papilla in the Japanese serow was covered with numerous small spines and numerous slender processes delivered from the lateral surface of the surrounding wall (Yamaguchi et al., 2002). In this study, the connective tissue core of the vallate papilla was covered with numerous small spines.

In the order Perissodactyla, the filiform papillae on the lateral sides of the lingual apex and body of the black rhinoceros had a hair-like shape, and consist of main papillae and some smaller secondary papillae (Emura et al., 2000b). The fungiform papillae were scattered among the hair-like papillae (Emura et al., 2000b). On the lingual apex of the donkey, the filiform papillae were abundant with more or less slim cylindrical form with pointed endings (AbdElnaeim et al., 2002). On the caudal part of the body, the filiform papillae were thinner than those on the apex, very long, cylindrical and abundant (Abd-Elnaeim et al., 2002). 

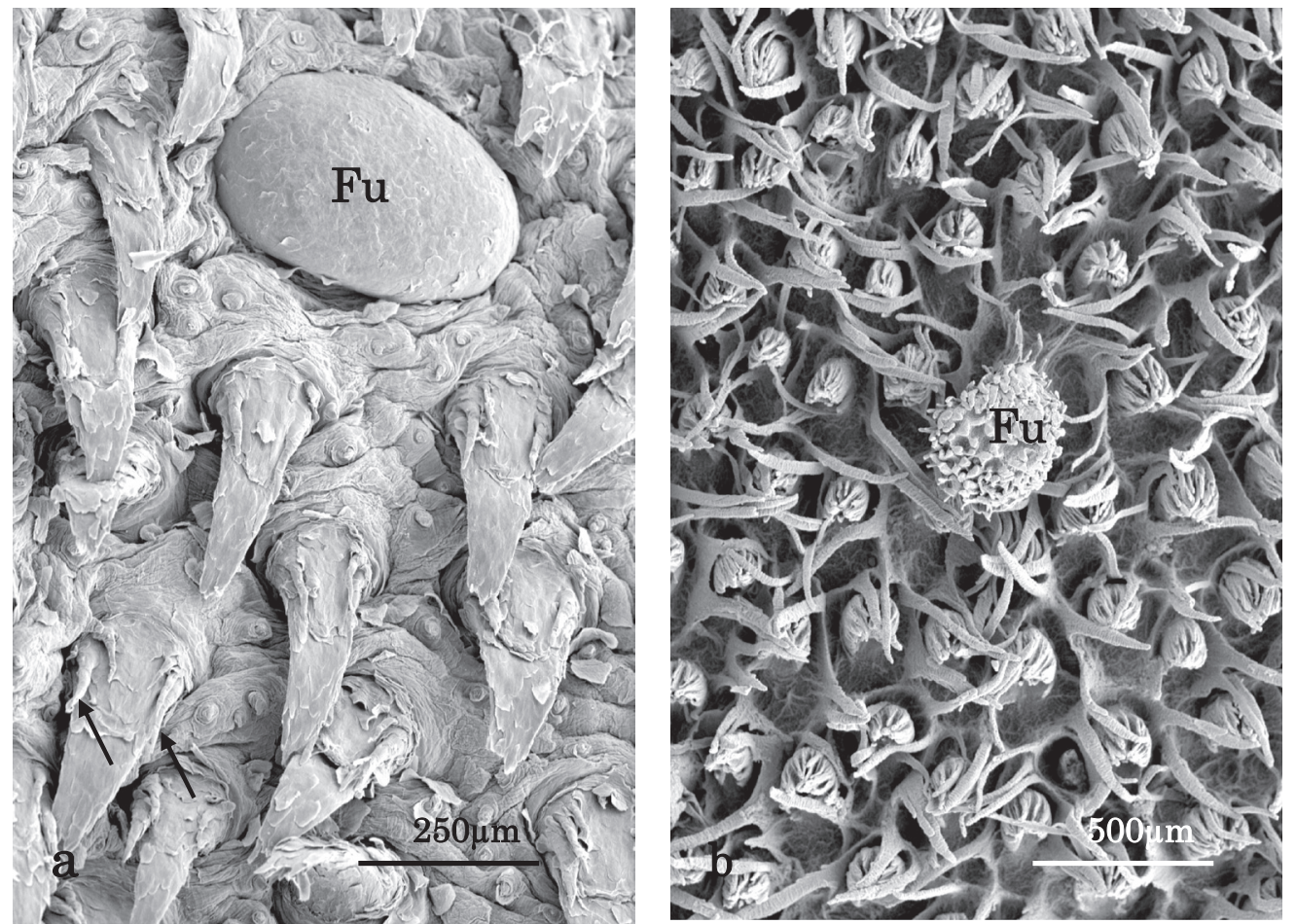

Fig. 2. Scanning electron micrographs of the lingual apex of the sitatunga. (a) A filiform papilla on the apical surface consists of a main papilla and secondary papillae. The fungiform papillae are round in shape. $\mathrm{Fu}=$ fungiform papilla. Arrows $=$ secondary papillae. (b) The filiform papilla contains a connective tissue core consisting of several processes. The connective tissue core of the fungiform papilla is flower-bud shaped. Arrow $=$ fungiform papilla.
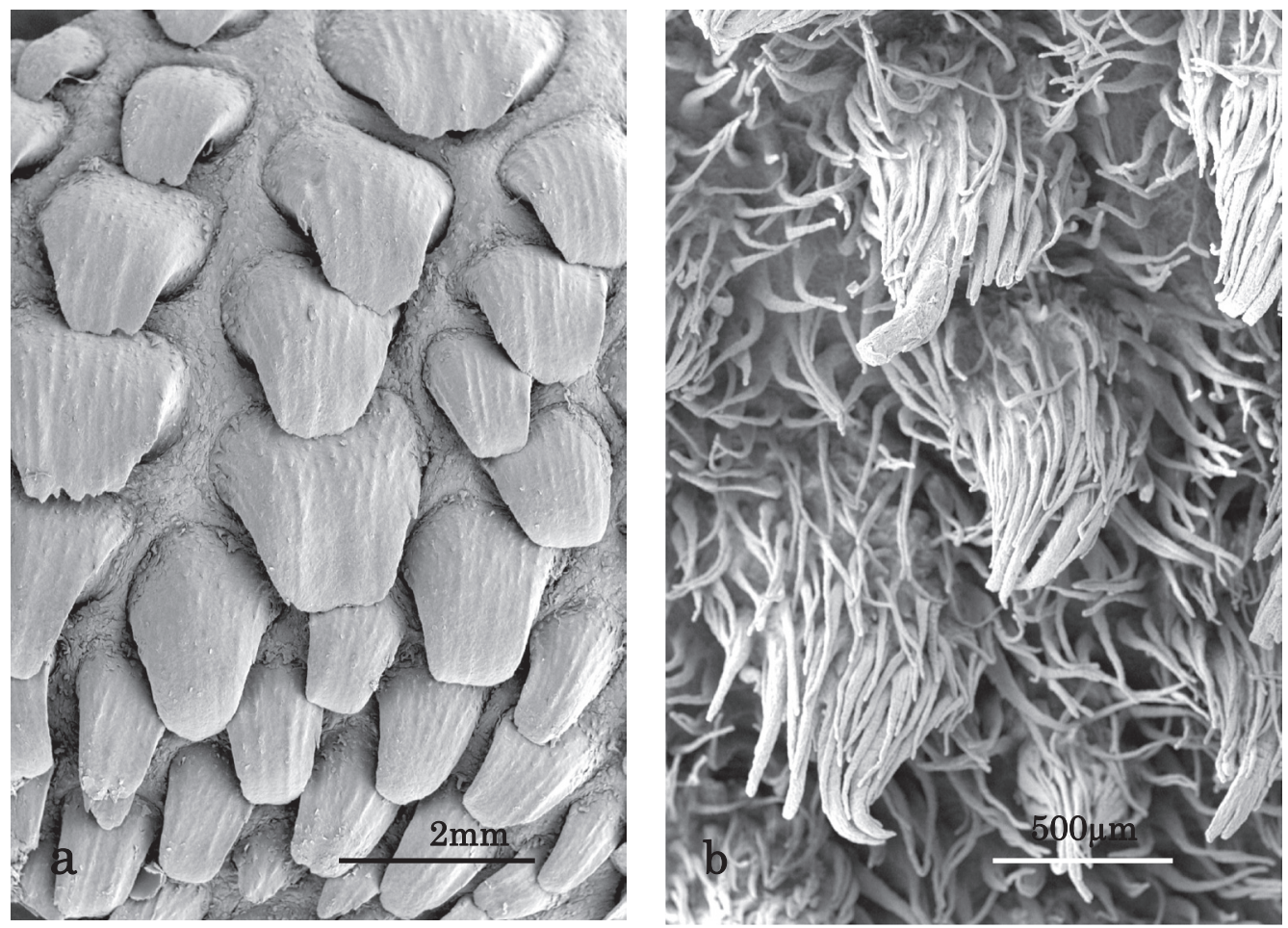

Fig. 3. Scanning electron micrographs of the lingual prominence of the sitatunga. (a) Lenticular papillae of various sizes are observed. (b) The connective tissue core of the lenticular papilla is covered with numerous small spines or rod-shaped processes of secondary connective tissue cores. 

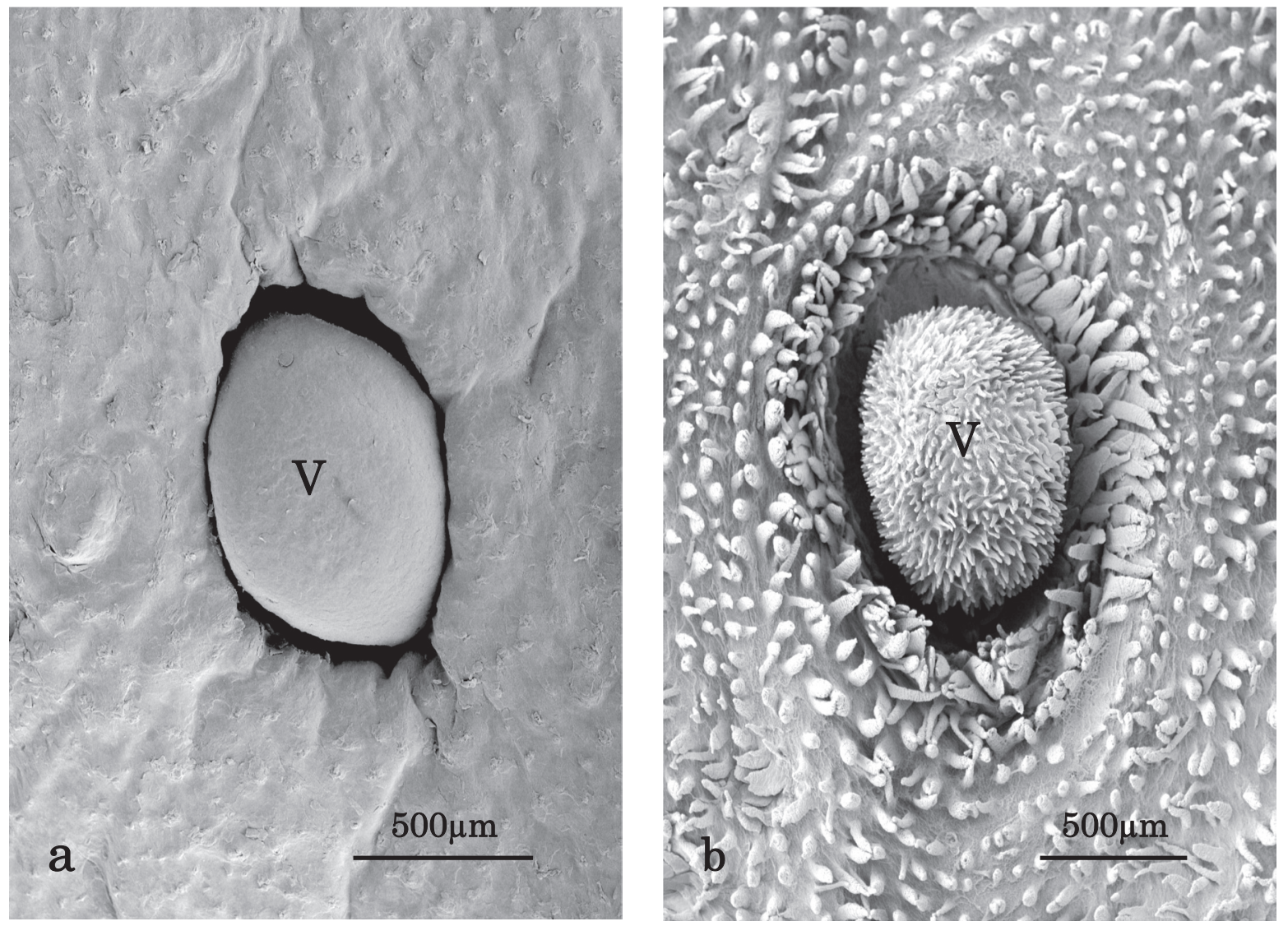

Fig. 4. Scanning electron micrographs of the vallate papilla of the sitatunga. (a) The vallate papillae are flattened-oval shaped and the papillae are surrounded by a semicircular trench. (b) The connective tissue core of the vallate papilla is covered with numerous small spines. $V=$ vallate papilla.

\section{Acknowledgements}

We are grateful to the staff of Himeji Central Park for supplying the specimen.

\section{References}

1) Abd-Elnaeim MMM, Zayed AE and Leiser R. Morphological characteristics of the tongue and its papillae in the donkey (Equus asinus): a light and scanning electron microscopical study. Ann Anat 2002; 184:473-480.

2) Agungpriyono S, Yamada J, Kitamura N, Nisa C, Sigit K and Yamamoto Y. Morphology of the dorsal lingual papillae in the lesser mouse deer, Tragulus javanicus. J Anat 1995; 187:635-640.

3) Atoji Y, Yamamoto $Y$ and Suzuki Y. Morpholog of the tongue of a male Formosan serow (Capricornis crispus swinhoei). Anat Histo1 Embryol 1998; 27:17-19.

4) Chamorro CA, de Paz P, Snadval J and Fernandez JG. Comparative scanning electron-microscopic study of the lingual papillae in two species of domestic mammals (Equus caballus and Bos Taurus). I. Gustatory papillae. Acta Anat 1986; 125:83-87.
5) Eerdunchaolu, Takehana K, Yamamoto E, Kobayashi A, Cao G, Baiyin, Ueda $\mathrm{H}$ and Tangkawattana P. Characteristica of dorsal lingual papillae of the Bactrian camels (Camelus bactrianus). Anat Histol Embryol 2001; 30:147-151.

6) Emura S, Agungpriyono A and Atoji Y. Scanning electron microscopic studies on the connective tissue cores of the lingual papillae of lesser mouse deer. 2008; 48:25-29.

7) Emura S, Tamada A, Hayakawa D, Chen H and Shoumura S. Morphology of the dorsal lingual papillae in the Barbary sheep, Ammotragus lervia. Okajimas Folia Anat Jpn 2000a; 77:39-46.

8) Emura S, Tamada A, Hayakawa D, Chen H and Shoumura S. Morphology of the dorsal lingual papillae in the black rhinoceros (Diceros Bicornis). Anat Histol Embryol 2000b; 29:371-374.

9) Emura S, Tamada A, Hayakawa D, Chen H, Yano R and Shoumura S. Morphology of the dorsal lingual papillae in the blackbuck, Antilope cervicapra. Okajimas Folia Anat Jpn 1999; 76:247254.

10) Funato H, Atoji Y, Suzuki Y and Sugimura M. Morphological studies on the tongue of wild Japanese serow, Capricornis crispus (in Japanese). Res Bull Fac Agr Gifu Univ 1985; 50:205-219.

11) Qayyum MA, Fatani JA and Mohajir AM. Scanning electron microscopic study of the lingual papillae of the one humped camel, Camelus dromedaries. J Anat 1988; 160:21-26. 
12) Scala G, Pelagalli GV, Vittoria A and Girolamo P. Etude morphostructurale des papilles linguales chez le buffle (Bubalus bubalis). Anat Histol Embryol 1993; 22:264-272.

13) Steflik DE, Singh BB, Mckinney RV and Boshell JL. Correlated TEM, SEM, and histological observations of filiform papillae of the cow tongue. Acta Anat 1983; 117:21-30.

14) Yamaguchi $T$, Asami $T$ and Kobayashi K. Comparative anatomical studies on the stereo structure of the lingual papillae and their connective tissue cores in the Japanese serow and bighorn sheep (in
Japanese). Jpn J Oral Biol 2002; 44:127-141.

15) Yoshimura K, Hama N, Shindo J, Kobayashi K and Kageyama I. Light and scanning electron microscopic study on the tongue and lingual papillae of the common hippopotamus, Hippopotamus amphibious amphibious. Anat Rec 2009; 292:921-934.

16) Yoshimura K, Kumakura M, Koizumi K, Abe T, Yamaguchi $T$ and Kobayashi K. Comparative morphological study on the stereostructure of the lingual papillae and their connective tissue cores of the pronghorn (in Japanese). Shigaku 2000; 88:47-57. 
